\title{
Hurdles Faced by Primary School Heads and Teachers in the Implementation of the Agriculture Curriculum in Seke District of Zimbabwe
}

\author{
John Tenha, Francis Ndlovu, Michael Mhlanga \\ Lecturer, Faculty of Education, Zimbabwe Open University
}

*Corresponding Author: John Tenha, Lecturer, Faculty of Education, Zimbabwe Open University

\begin{abstract}
This study sought to investigate the challenges faced by primary schools in the teaching of agriculture. The study will employ the quantitative paradigm and adopt the descriptive survey design. The population comprises of all primary schools in Seke District. The sample comprises of 220 respondents made up of 20 heads of schools and 200 teachers of which 53\% were male and 47\% female. Data will be collected using a questionnaire which has both close-ended and open-ended questions. Descriptive statistical analysis will be used to interpret data.
\end{abstract}

Keywords: Primary schools, implementation, agriculture, curriculum, challenges and district

\section{INTRODUCTION}

According to Gatawa (2008) prior to the independence of Zimbabwe, education was used as an instrument of social and political segregation. The system of education was dichomised according to racial lines; whites had superior first class education while the majority blacks were offered either second or third rate practical schooling (Gatawa, 2008). As Zvobgo (1994) observed, vocational education was intended to prepare Africans for inferior roles in the colonial society and rural life.

As an attempt to resuscitate the education system and aligning it to the practical needs of the day, the Zimbabwean government made numerous changes to the educational structure. Amongst those changes, as Zvobgo (1994) alludes was the introduction of practical subjects in the secondary school sector. The teaching of agriculture in the primary schools became mandatory from 2014 when the subject became examinable (Mukoki, 2014). It was introduced as a means of giving pragmatic education to the young in whose hands the future of Zimbabwe lies (Mukoki, 2014).

From 2014 agriculture is a mandatory subject in all primary schools in Zimbabwe from grade four (4) to seven (7). The Primary School Agriculture syllabus states that the teaching of this subject in primary schools aims to: develop a positive attitude towards agriculture and its study as an applied science; develop agricultural business skills and lay out foundations for an occupation in the field of agriculture among other aims. It is on account of the information above that this research set out to establish the challenges that primary school heads and teachers experience as they attempt to implement this subject in their schools.

\section{LITERATURE REVIEW}

Teaching agriculture to young, primary school children opens them to understanding how things grow, live and die (Carver, 2013). From flowers to potatoes, from cows and pigs to tractors and soil, teaching students about farming and gardening introduces knowledge about how for example, food gets onto their tables, clothes get onto store shelves, and seeds germinate (Carver, 2013). This, therefore implies that starting agricultural, education at a young age helps children's perspectives on their lives and the world around them. As Mason (2003) argues, the introduction of agriculture in primary schools has three principal motives which are education; which include the desire to give vocational and prevocational orientation and to give agricultural training to pupils; economic; which is to impart skills and knowledge on future agricultural employees and entrepreneurs as well as 
Hurdles Faced by Primary School Heads and Teachers in the Implementation of the Agriculture Curriculum in Seke District of Zimbabwe

generate pupils' interests in future agricultural investments and finally socio-political objectives; where agriculture is meant to empower students give them skills which will help them to produce food for themselves and benefit them through poverty reduction and economic empowerment.

The introduction of Agriculture science as a major school subject in Africa started in Nigeria in the early sixties (Mock, 2010). However, the realization of the courses primary goals of imparting knowledge on the pupils on basic principles of the course as well as motivating the pupils to develop interest in agriculturally inclined professions failed dismally as a result of a number of factors which include among others, pedagogical approaches (Mock, 2010). Teachers did not have any training in the subject itself or the teaching of the subject. As Chenevey et.al (2008) postulate, before the introduction of any course it is necessary to assess the skills of the available staff and determine whether they tally with the requirements of the course. Teaching of agriculture requires a sound background in theory and practical aspects by the teachers of the subject. As Obi (2005) states, the delivery of practical agriculture at school level should not be handled as a science per se, but rather as a vocational subject for acquisition of practical agricultural skills for meaningful living, which means that the skills pupils acquire from agriculture should make them functional and productive citizens.

According to Myer et.al (2005) several lapses associated with the organization of practical agriculture in Nigerian schools have been identified. The curriculum objectives were found to be too broad, there is the inability of the policy to state general aims of vocational education. Other lapses include inability to identify areas where practical skills are to be developed, unspecified evaluation system, cases of duplicated topics and poor programme delivery system. As Obi (2005) argue lack of instructional aids and materials for practical agriculture delivery, lack of means and ability to provide recommended guest lecture visits and excursions. The teaching and learning activities of practical agriculture are grossly insufficient to elicit the desired level of initiative and creativity in students (Obi, 2005). According to Akoto-senaman (2010) instructional strategies in the teaching of agriculture in Nigerian schools is full of "showing", telling, and "observing" with a few cases of "doing" and "practice" thus contradicting the recommended "learning by doing" and guided discovery instructional strategies.

In Zimbabwe Mungazi (2011) found that negative attitudes affected the successful implementation of education with production. Historically, practical subjects in the Zimbabwean school system were given to the academically challenged pupils and this tended to create a stigma on pupils who undertook the subjects (Mungazi, 2011). In most cases, tghose pupils who opted to participate in the agricultural projects were viewed as weak. Peresu and Nhundu (2009) opine that one of the challenges in introducing agriculture as a core subject in schools is the perception of parents on the subject; parents tend to have negative perceptions of the subject and fee; it is not at all beneficial to their children. Rather than the subject benefiting their children, some parents feel that teaching agriculture to pupils is nothing but a process of "ruralising" the educational system (Peresu and Nhundu, 2009). This kind of mindset will then be transferred to the children through family discussions and social talks which will eventually lead to children developing negative attitudes towards the subject.

According to Kisirikoi and Malusu (2008) teaching learning resources are all materials and equipment used to enhance effective learning. A teacher selects, develops and reorganizes teaching-learning resources for effective teaching and the teacher therefore is the most important teaching-learning resource (Waithera, 2013). Learning resources play a key role as far as learning is concerned. Douglas (1964) in Waithera (2013) argues that good teachers as they teach keep in mind both what they teach and what they teach with and the quality and adequacy of resources such as physical facilities, equipment will establish whether this is the case. In Mozambique, poor teacher training, insufficient materials and lack of pedagogical support has meant that most teachers rely on teachercentred didactic methods, emphasizing repetition and memorization over learner-centred approaches that encourage creative thinking and skills-based learning. Teachers are poorly equipped to deal with some of the challenges that the system poses such as the reality of large class sizes, unavailability of didactic materials and gender disparities (Waithera, 2013).

In Kenya as Ngesa (2006) in Waithera (2013) observe, teachers of agriculture use lecture, class discussion and group discussion methods. Demonstrations, practical, experiments, projects and problem-solving are hardly used. In Nigeria, the greatest problem facing agriculture education is 
Hurdles Faced by Primary School Heads and Teachers in the Implementation of the Agriculture Curriculum in Seke District of Zimbabwe

attitudinal factors such as cultural traditions, early childhood socialization, parental expectations, the actual hard work involved in manual labour, the reward that go with it, the behavior and attitude of teachers, influence the attitude the pupils require (Waithera, 2013).

The above literature has revealed that agriculture as a school subject plays a very crucial role in conscientising young people about food production and poverty eradication which promote human development. However, there are structural and attitudinal obstacles in the schools that inhibit the proper implementation of agriculture and the empirical aspects of this study sought to find out to what extent challenges that teachers and heads in primary schools in Zimbabwe experienced were affecting the implementation of the agriculture curriculum.

\section{STATEMENT OF THE PROBLEM}

The introduction of agriculture in Zimbabwean primary school was done to empower the young people rather than to relegate them to low social rungs or prepare them for rural life as was the situation during the colonial era. Teaching agriculture to young children is a means of giving pragmatic education with the view of making sure that schools generate future employers rather than employees. If properly taught, agriculture at primary school level has the potential to incalculate values of self-sufficiency in food production as well hard work as for anyone to be a successful former, they have to work very hard. Thus, the importance of agriculture as a school subject cannot be overemphasized.

\section{RESEARCH QUESTIONS}

The research will be guided by the following questions.

1. What are teachers' attitudes towards the teaching of agriculture in the primary schools?

2. Is the agriculture syllabus relevant for effective teaching of the subject?

3. What are the major challenges that teachers face in the teaching of agriculture?

4. How best can challenges faced by teachers in the teaching of agriculture be solved?

\section{SIGNIFICANCE OF THE STUDY}

The study's importance stems from the fact that it hopes to highlight the challenges experienced by primary school teachers in their attempts to implement the new agriculture curriculum and come up with concrete suggestions to ameliorate these challenges both at policy and operational levels.

\section{LIMITATIONS OF THE STUDY}

The first limitation has to do with the descriptive method used in the study. As Tuckman (2012) argues, the descriptive method lacks predictive power since the research may discover and describe "what is" and unable to predict "what would be". In view of the small size of the sample, the findings of the study therefore, would have limited generalisability.

\section{DELIMITATION OF THE STUDY}

The study confines itself to investigating the challenges faced by primary school teachers and heads as they attempt to implement the agriculture curriculum using a sample of 200 teachers and 20 heads of schools from Seke District in Mashonaland East Province of Zimbabwe. Views from Education Inspectors, Provincial Education Directors and Civil Service Inspectors will be outside the purview of this study.

\section{Methodology}

The study employs the quantitative methodology and makes use of a survey research design. The questionnaire will be used as the sole instrument for collecting data. All the questionnaires will be given to the respondents directly by the researcher. The researcher will also collect the questionnaires personally in order to increase on rate of return of the instrument. As a result, all the questionnaires were returned and there was no problem with non-returns. According to Phillips and Pugh (2011) non-returns introduce a bias in as much as they are likely to differ from respondents in many ways thereby adversely affecting reliability and validity of the findings. Permission was sought from the 
Hurdles Faced by Primary School Heads and Teachers in the Implementation of the Agriculture Curriculum in Seke District of Zimbabwe

Ministry of Primary and Secondary Education before the fieldwork started and respondents will be assured of anonymity and also participate voluntarily. Data collected through the questionnaire will produce descriptive statistics around the variables under and these statistics and will be computed and inferential implications from them derived.

\section{FINDINGS AND DISCUSSION}

The study set to establish the challenges experienced by teachers during the teaching of agriculture in Zimbabwean primary schools. This section is presented in two parts, namely, presentation of data and discussion thereof.

\section{Presentation of data}

Table1. Composition of respondents by category $(N=220)$

\begin{tabular}{|l|c|c|}
\hline Response Category & Frequency & Percentage \\
\hline Heads & 20 & 9 \\
Teachers & 200 & 91 \\
\hline Totals & $\mathbf{2 2 0}$ & $\mathbf{1 0 0}$ \\
\hline
\end{tabular}

The information on Table 1 above shows that teachers constituted $91 \%$ of the respondents and heads $9 \%$. The sample fully represents both categories of respondents in the school system as all schools have one head and many teachers.

Table2. Distribution of respondents by sex $(N=220)$

\begin{tabular}{|l|c|c|c|c|c|c|}
\hline \multirow{2}{*}{ Category } & \multicolumn{2}{|c|}{ Heads } & \multicolumn{2}{c|}{ Teachers } & \multicolumn{2}{c|}{ Totals } \\
\cline { 2 - 8 } & Frequency & $\mathbf{\%}$ & Frequency & $\mathbf{\%}$ & Frequency & \% \\
\hline Male & 16 & 80 & 94 & 47 & 110 & 50 \\
Female & 4 & 20 & 106 & 53 & 110 & 50 \\
\hline Totals & $\mathbf{2 0}$ & $\mathbf{1 0 0}$ & $\mathbf{2 0 0}$ & $\mathbf{1 0 0}$ & $\mathbf{2 2 0}$ & $\mathbf{1 0 0}$ \\
\hline
\end{tabular}

Data from Table 2 above reveals that there were more male heads of schools than female ones $(80 \%$ and $20 \%$ respectively) and yet there were more female teachers than male ones (53\% and $47 \%$ respectively). The totals for both categories show that there was a sex balance of respondents $(50 \%)$ of each.

Table3. Composition of respondents by professional qualifications $(N=220)$

\begin{tabular}{|l|c|c|c|c|c|c|}
\hline \multirow{2}{*}{ Response category } & \multicolumn{2}{|c|}{ Heads } & \multicolumn{2}{c|}{ Teachers } & \multicolumn{2}{c|}{ Totals } \\
\cline { 2 - 7 } & Frequency & $\mathbf{\%}$ & Frequency & $\mathbf{\%}$ & Frequency & \% \\
\hline Untrained & 0 & 0 & 22 & 11 & 22 & 10 \\
\hline Certificate in Education & 2 & 10 & 13 & 6 & 15 & 7 \\
\hline Diploma in Education & 4 & 20 & 122 & 61 & 126 & 57 \\
\hline Certificate in Agriculture & 0 & 0 & 0 & 0 & 0 & 0 \\
\hline Bachelor's degree & 14 & 70 & 43 & 22 & 57 & 26 \\
\hline Others & 0 & 0 & 0 & 0 & 0 & 0 \\
\hline Totals & $\mathbf{2 0}$ & $\mathbf{1 0 0}$ & $\mathbf{2 0 0}$ & $\mathbf{1 0 0}$ & $\mathbf{2 2 0}$ & $\mathbf{1 0 0}$ \\
\hline
\end{tabular}

Information on Table 3 above reveals that all heads and the majority of teachers are in possession of professional qualifications (heads: 100; teachers: $89 \%$ respectively). Only $11 \%$ of the teachers did not hold a professional qualification. None of the respondents had done the Certificate in Agriculture course offered by Agriculture Colleges found across the country.

Table4. Responses to the statement: "I did agriculture as a subject at secondary school" $(N=220)$

\begin{tabular}{|l|c|c|c|c|c|c|}
\hline \multirow{2}{*}{ Category } & \multicolumn{2}{|c|}{ Heads } & \multicolumn{2}{c|}{ Teachers } & \multicolumn{2}{c|}{ Totals } \\
\cline { 2 - 8 } & Frequency & \% & Frequency & \% & Frequency & \% \\
\hline Yes & 7 & 35 & 65 & 32 & 72 & 33 \\
No & 13 & 65 & 135 & 68 & 148 & 67 \\
\hline Totals & $\mathbf{2 0}$ & $\mathbf{1 0 0}$ & $\mathbf{2 0 0}$ & $\mathbf{1 0 0}$ & $\mathbf{2 2 0}$ & $\mathbf{1 0 0}$ \\
\hline
\end{tabular}

The majority of both teachers and heads indicated that they did not do agriculture as a secondary school subject (Heads: 65\%; and teachers: 68\% respectively). Those who stated that they learnt agriculture at secondary school constituted $35 \%$ for heads and $32 \%$ for teachers. 
Hurdles Faced by Primary School Heads and Teachers in the Implementation of the Agriculture Curriculum in Seke District of Zimbabwe

Table5. Responses to the statement: I did agriculture during my teacher training $(N=220)$

\begin{tabular}{|l|c|c|c|c|c|c|}
\hline \multirow{2}{*}{ Response Category } & \multicolumn{2}{|c|}{ Heads } & \multicolumn{2}{c|}{ Teachers } & \multicolumn{2}{c|}{ Totals } \\
\cline { 2 - 7 } & Frequency & $\mathbf{\%}$ & Frequency & $\mathbf{\%}$ & Frequency & $\mathbf{\%}$ \\
\hline Yes & 12 & 60 & 42 & 21 & 33 & 25 \\
No & 8 & 40 & 158 & 79 & 166 & 75 \\
\hline Totals & $\mathbf{2 0}$ & $\mathbf{1 0 0}$ & $\mathbf{2 0 0}$ & $\mathbf{1 0 0}$ & $\mathbf{2 2 0}$ & $\mathbf{1 0 0}$ \\
\hline
\end{tabular}

The information on table 5 above shows that there is a discrepancy in the responses of heads and teachers on this item. Whereas $60 \%$ of the heads of schools indicated that they did agriculture during their teacher training at colleges, a significant number of teachers (79\%) indicated that they did not do the subject during their teacher training.

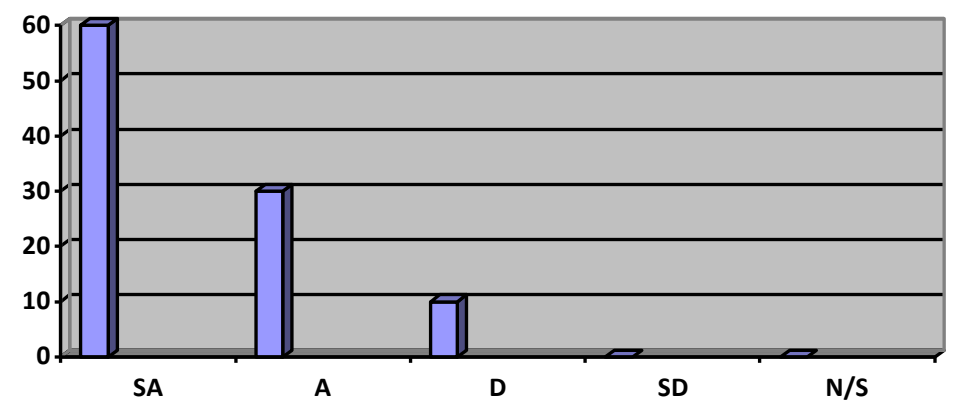

\begin{tabular}{|l|}
\hline SA-Strongly Agree \\
$\square$ A- Agree \\
$\square$ D- Disagree \\
$\square$ SD-Strngly Disagree \\
$\square$ NS-Not Sure
\end{tabular}

Figure1. Responses to the question: "Do you think that all primary pupils from Grade 4 to Grade 7 should be compelled to do agriculture?" $(N=220)$

The majority of respondents (90\%) indicated that all primary pupils from Grade 4 to Grade 7 should do agriculture as a compulsory subject. A paltry $10 \%$ indicated that the subject should not be forced on primary school pupils.

The questionnaire had two-open-ended questions which bolstered responses from the close-ended questions. The first question sought to find out from the respondents what challenges they faced as they attempted to implement the agriculture curriculum. The most common challenges are listed below in order of popularity.

- Lack of resources like textbooks and equipment $-93 \%$.

- Very little time allocated to teach the subject $-89 \%$.

- Lack of knowledge on the subject by teachers and heads $-85 \%$.

- Syllabus aims are too broad $-83 \%$.

- The subject is too theoretical $-81 \%$.

- Subject has added more workload for teachers, heads and pupils $-77 \%$.

- Supervision on the subject not a priority $-72 \%$.

The second question wanted to find out from the respondents how parents and pupils felt about the introduction of agriculture. The overwhelming majority of the respondents stated that most parents and pupils welcomed the teaching of the subject. A few parents however, were said to be of the opinion that primary school pupils were too young to do practical subjects especially the lower grades.

\section{DisCUSSION}

The study reveals that there were more male heads than females and yet there were more female teachers than male ones. The implications of this revelation are that most pupils were most likely to be in the hands of teachers with very little knowledge on agriculture as it is the general trend that most female teachers would prefer "feminine" practical like food and nutrition and fashion and fabrics 
Hurdles Faced by Primary School Heads and Teachers in the Implementation of the Agriculture Curriculum in Seke District of Zimbabwe

subjects both at school and college during their learning days (Ramsay abd Edwards, 2011). The positive development revealed by the study is that most of the heads have some basic knowledge on agriculture. This would enable them to guide and supervise teachers easily since they understand the demands of the subject.

Most teachers and heads have positive attitudes towards the teaching of agriculture. Attitudes play a critical role in the implementation of a new curriculum. Research has demonstrated a relationship between teacher attitude towards a curriculum and its ultimate effectiveness (Pretty and Boone, 2009; Mason, 2003; Myer et. al, 2005 and Carver, 2013). The advantage of having teachers exhibiting positive attitudes towards a subject are many. However, as Fullan (2010) postulates the most important advantage of having teachers with a positive attitude towards a subject is that the teachers can easily influence parents and students as well.

The majority of teachers in this study did not do agriculture either at secondary school or during teacher training. The ramifications of this data are that it would be difficult for effective implementation of the subject if teachers have no knowledge to impart to pupils. As Mock (2010) argues the realization of the primary goals of introducing agriculture in schools which is to impart knowledge on the pupils on basic principles of the course as well as motivating the pupils to develop interest in agriculturally inclined professions failed dismally as a result of a number of factors which include among others; pedagogical approaches. Teachers did not have any training in the subject itself or the teaching of the subject. As Chenevey et.al (2008) postulate, before the introduction of any course it is necessary to assess the skills of the available staff and determine whether they tally with the requirements of the course.

The major challenges experienced by school during the implementation of the agriculture curriculum included lack of resources like textbooks and equipment; very little time allocated to agriculture; too broad syllabus aims; workload due to the addition of agriculture as a compulsory subject as well as supervision on the subject. This finding tallies with observations by Myer et.al (2005) who found several lapses with the organization of practical agriculture in Nigerian schools. The curriculum objectives were found to be too broad; inability of the policy to state general aims of vocational education; inability to identify areas where practical skills are to be developed, unspecified evaluation system as well as cases of duplicated topics and programme delivery system. Obi (2005) corroborates Myer et.al (2005)' observation when he states that lack of instructional aids and materials for practical agriculture deliver, lack of means and ability to provide recommended guest lecture visits and excursions. According to Ngesa (2006) in Waithera (2013) observed, teachers of agriculture use lecture class discussion and group discussion methods, and demonstrations practical experiments, projects and projects problem-solving are hardly used.

\section{CONCLUSIONS}

Given the background of the above findings, it becomes evident that primary school heads and teachers in Lupane District believe that agriculture is a necessary subject in the Zimbabwean school curriculum and by implication, are therefore prepared to give vocational and prevocational orientation to the young children under their tutelage on this subject. However, in spite of their positive attitudes towards agriculture, the majority of the teachers in this study did not do agriculture either at secondary school or during teacher training. Fortunately, though, is the fact that most of the heads have some basic knowledge on the subject which makes it relatively easier for them to guide teachers as they implement this curriculum. It is also evident that primary schools in this study are experiencing a number of challenges with the teaching and learning of agriculture. These include lack of tools and equipment which are key to teaching of agriculture since it is a practical subject and this requires huge investments in movable and immovable asserts. The time allocated to teaching of the subject is also inadequate and its introduction has further worsened the workload of primary school teachers and pupils who have to contend with over eleven subjects on a daily basis.

\section{RECOMMENDATIONS}

In light of the findings of this study, the researchers would like to make some recommendations:

- The Ministry of Primary and Secondary Education should recruit specialist agriculture teachers from agricultural colleges and deploy them in the primary schools so that they promote the proper teaching of the subject. Presently, most of these are deployed in secondary schools in Zimbabwe. 
Hurdles Faced by Primary School Heads and Teachers in the Implementation of the Agriculture Curriculum in Seke District of Zimbabwe

- For those teachers who did not do agriculture at college, there should be in-service courses and staff development sessions where experts in agriculture should be invited to facilitate and guide the teachers.

- The government should assist schools acquire agricultural inputs and implements through being a guarantor for them when they apply for bank loans.

- The Ministry of Primary and Secondary Education should consider reviewing its primary school curriculum so that the number of subjects offered is reduced in order to create more time for agriculture which is a very important subject in the lives of children and for the economic survival of a nation.

\section{REFERENCES}

Akofo-senaman, M. (2010). Challenges in the teaching and learning of practical agriculture. Cape Coast: University of Cape Coast.

Carver, N. (2013). Importance of teaching agriculture to the primary schools. Vanvouver: FAO Newsroom.

Chenevey, J. L., Ewing, J. C. and Whittington, M. S. (2008). Teacher burnout and job satisfaction among agricultural education teachers. Journal of Agricultural Education, 49(3):12-22.

Gatawa, B.S.M. (2008). The politics of the school curriculum. An introduction. Harare: College Press Publishers.

Kisirikoi, F. and Malusu, J. (2008). Distinction teacher education for primary teacher education. Nairobi: Kenya Literature Bureau.

Mason, J. (2003). Sustainable agriculture. London: Landlinks Press.

Mock, B. T. (2010). Investing in agriculture. London: Longman.

Mukoki, A. (2014). Sustainable farming. Harare: Longman.

Mungazi, D. A. (2011). Colonial education for Africans: George Stark's policy in Zimbabwe. New York: Praeger Publishers.

Myer, B. E., Dyer, J. E. and Washburn, S. G. (2005). Problems facing beginning agriculture teachers. Journal of Agricultural Education, 46(3):47-55.

Obi, C. J. (2005). A critique of vocational agriculture education in Nigerian Senior secondary schools. Journal of Home Economics Research, 6 (2): 57-61.

Peresu, B. and Nundu, R. (2009). Agriculture before independence in Zimbabwe. Harare: College Press Publishers.

Phillips, G. and Pugh, C. (2011). Research methods. London: Routledge.

Tuckman, B. (2011). Conducting educational research. New York: Thompson learning.

Waithera, K. S. (2013). Challenges to teaching and learning of agriculture in secondary schools in Kakuyini division. Nairobi: Kenyattan University.

Zvobgo, R. J. (1994). Education in Zimbabwe. Gweru: Mambo Press. 
Hurdles Faced by Primary School Heads and Teachers in the Implementation of the Agriculture Curriculum in Seke District of Zimbabwe

Citation: John Tenha et al. " Hurdles Faced by Primary School Heads and Teachers in the Implementation of the Agriculture Curriculum in Seke District of Zimbabwe" International Journal of Humanities Social Sciences and Education (IJHSSE), vol 8, no. 7, 2021, pp. 103-110. doi: https://doi.org/10.20431/2349- 0381.0803012.

Copyright: (C) 2021 Authors. This is an open-access article distributed under the terms of the Creative Commons Attribution License, which permits unrestricted use, distribution, and reproduction in any medium, provided the original author and source are credited. 